\title{
A LISTENING TO WALT WHITMAN AND JAMES WRIGHT
}

GeORge Yatchisin

JAMES WrighT'S ESSAY, "The Delicacy of Walt Whitman," published in 1962, might have saved Wright's poetic career. The four years between his books Saint Fudas (1959) and The Branch Will Not Break (1963) were clearly tumultuous ones; Wright has said in a 1972 interview that "a certain kind of poetry had come to an end, and I thought that I would stop writing completely." 1 Nowhere does he record an "A-ha!" experience while reading Leaves of Grass. But the "Delicacy" essay might be a hint that Whitman helped him find a new turning in his verse. ${ }^{2}$ The essay breaks into four parts: Wright discusses the three types of delicacy-music, diction, form - he finds in Whitman, and ends by discussing contemporary poets open to Whitman (the Spanish, Robert Bly, Denise Levertov, Louis Simpson, David Ignatow).

But the essay digresses almost immediately when Wright spends three pages illuminating Whitman's own relationship to the past. Here Wright justifies the essay's existence, claiming, "And the most difficultly courageous way of asserting the shape and meaning of one's own poetry and one's own life [always these two together in Wright, and clearly one of the reasons he values Whitman so] is to challenge and surpass those very traditions and masters whom one can honestly respect" (Prose, 5).

This essay's relationship to the past, then, is to read Wright in one hand and Whitman in the other; to learn the lessons Wright learned, and expand on the challenges he found in his master Whitman. An essay such as this one becomes necessary because Wright took delicacy very seriously, and therefore his essay is more suggestive than full: Wright seems eager to nudge us towards a poem or two of Whitman's and have us discover on our own. Wright, when lauding the famous line from "Song of Myself," "I was the man, I suffered, I was there," characterizes it as "almost as unobtrusive as a stage-direction or perhaps a whispered aside to the reader" (Prose, 11), and in a way characterizes his own examination of Whitman-we must look hard to find what he whispers softly about.

To complete Wright's essay, it becomes necessary to do work many might find critically trivial; it becomes necessary to scan poetry and perform line-by-line exegesis. This essay will read through Wright's essay to test his claims and to find what he says we can find in Whitman. 
And to go beyond Wright's own examples, this essay will also look further into Wright's poems and prose, to see other echoes of these lessons he learned from Whitman, even if no direct correspondence is clear. Whitman was clearly one of Wright's ear-tunings. So by learning what Wright learned from Whitman, we also learn what there is to learn in Whitman.

\section{In 1962 Wright wrote:}

Whitman's poetry has a delicacy of music, of diction, of form. The word 'delicacy' can do without a rhetorically formal definition; but I mean it to suggest powers of restraint, clarity, and wholeness, all of which taken together embody that deep spiritual inwardness, that fertile strength, which I take to be the most beautiful power in Whitman's poetry, and the most readily available to the poetry, and indeed the civilization, of our own moment in American history. (Prose, 4)

Beyond the Whitmanesque length of this sentence, the urgency Wright felt is clear; he's not merely worried about aesthetic rules, he's worried about civilization and history. Wright's rhetorical situation becomes crucial to understanding his essay. Wright feels he has two forces to fight, each equally ominous. First, the Beats must be beaten back, ${ }^{3}$ as must every person who ignores Whitman's own warning, quoted and italicized by Wright, "I do not intend this as a warrant for wildness and frantic escapades' " (quoted in Prose, 11).

Second, someone needs to jostle poets like Wright himself in his first two books, poets creating well-wrought urns like Longfellow did, Longfellow, that " "poet of melody, courtesy, deference-poet of the mellow twilight of the past' " (quoted in Prose, 7). Wright turns the image of Whitman around, hoping to define him as "one of the roughs" who inside is as gentle as a lamb. Then, he wants us to learn from that image, to write as delicately as that lamb.

Again, while Wright's own forecasting statement for his piece prepares us for four sections, his section on the delicacy of Whitman's music begins with what seems a subsection, a look to tradition; for as Wright claims, "Whitman realizes the past has existed" (Prose, 5). It is at this point that Wright offers the notion of challenging one's poetic masters already quoted. For Whitman, such a master is Longfellow. Wright goes to great pains to establish that Whitman valued Longfellow and in what ways. Referring to Specimen Days, specifically "The Death of Longfellow" and "My Tribute to Four Poets," Wright finds the precise point where Whitman parts Longfellow's company: " $\mathrm{He}$ strikes a splendid average, and does not sing exceptional passions, or humanity's jagged escapades. . . . His very anger is gentle, is at second hand" " (quoted in Prose, 7). Wright claims Whitman values the past, but feels he must "pass beyond. . . . [H]e tunes his verses towards those very crass and difficult subjects which Longfellow . . . avoided" (Prose, 
7). Why such painstaking movement and scholarship? Wright wants two things, to say Whitman wasn't merely a wild-man radical desperate for a clean break from all traditions and to say Wright has a reason for such scholarship. If Whitman could learn so much from Longfellow, then how much more can Whitman teach us? As Whitman himself wrote about the Poet in the 1855 Preface, "He drags the dead out of their coffins and stands them again on their feet . . . he says to the past, Rise and walk before me that I may realize you. He learns the lesson." 4

Wright's lesson may have begun even earlier than the writing of this essay. Further evidence that Whitman might have been central to Wright's movement away from rhyme and meter occurs by $1959 .^{5}$ "The Morality of Poetry" appears in Saint Fudas, and is headed by the epigraph, "Would you the undulation of one wave / its trick to me transfer . ...," from none other than Walt Whitman; the poem itself is a symbolic mess in randomly rhymed iambic pentameter. Wright tries to respond to another poet (one Gerald Enscoe) whose "human images come to pray for hands / To wipe their vision clear." Wright can't help, confused by the sea, which is both "sheer outrage" and "nothingness." Despite seeming advice like, "Before you let a single word escape / Starve it in darkness," the poem itself is too full of a sea that is more than a sea and birds that are more than birds, not to mention random allusions to "Out of the Cradle Endlessly Rocking." By the end Wright's mind is lost on the sea of language, and he sends us "shoreward echoes of my voice." He knows he has failed his task and has let us, and his fellow poet, down.

Perhaps Wright's confusions stem from his desire to emulate Whitman; he might already be struggling with lessons about how to discover new rules, since Wright admits in the poem that nature "flaunts to nothingness the rules I made." It turns out Wright's epigraph refers to Whitman honoring old rules; the lines occur in "Had I the Choice," one of Whitman's later, shorter lyrics. To examine the poem in the way Wright will soon look at Whitman's "Reconciliation" proves rewarding. Here is the entire poem:

Had I the choice to tally greatest bards,

To limn their portraits, stately, beautiful, and emulate at will, Homer with all his wars and warriors-Hector, Achilles, Ajax,

Or Shakespere's [sic] woe-entangled Hamlet, Lear, Othello-Tennyson's fair ladies,

Metre or wit the best, or choice conceit to wield in perfect rhyme, delight of singers;

These, these, O sea, all these I'd gladly barter,

Would you the undulation of one wave, its trick to me transfer,

Or breathe one breath of yours upon my verse,

And leave its odor there. ${ }^{7}$

The poem seems typical of later Whitman, down to the pyramidal shape of the stanza pointed out by Sculley Bradley as the most common stanza 
form in Whitman. ${ }^{8}$ Yet, listening closely to lines one and eight, it's clear Whitman is writing in precise iambic pentameter. Looking at Wright's epigraph allows us to hear more: What Wright prints as two lines is actually one, line seven of the poem. But given Wright's enjambment of the line, we're left with a line of iambic pentameter followed by a line of iambic trimeter. Similarly, lines two, three, and four all begin with iambic pentameter ghosts, despite their increasing length, while line five is actually two lines of iambic pentameter, the second complete with a feminine ending, or the amphibrach Paul Fussell claims Whitman uses to "recall classical heroic hexameter"9-quite fitting considering the previous march of Homer's soldiers.

The remaining lines also tell a metrical tale. Line six, the sudden, shortened plea to the sea after the break of the poem's wave, opens with an emphatic spondee, but otherwise fails to escape the iambic pentameter trap, despite its lingering feminine ending, possibly echoing Whitman's falling hope. The last line is inevitable-iambic trimeter, the unfastened hemstitch that elsewhere in the poem always has a line to hang on to for safety.

"Had I the Choice" is rarely dragged out beside "O Captain! My Captain!" as an example of Whitman writing meter. But without meter, the poem has no meaning. It's a bitterly sad lament from a poet who knows he has had no choice-he's stuck in the tradition and can never truly capture the sea's song. Man may be free, but everywhere he is in iambs. Hearing the poem this way illuminates Wright's choice of an epigraph, for with "The Morality of Poetry" he, too, is struggling, taken out to sea by his music. Elsewhere, Wright evades the overtly judgmental tone of the poem's title in an interview: "What I meant there was that there are different kinds of forms in poetry which are possible and to try to write any of them well is a good thing. That is the morality of poetry, as far as I'm concerned" (Prose, 222). So an "A" for effort is enough.

Enough, that is, if we never give up listening. Wright doesn't, which becomes more than clear when he turns to "Reconciliation" as the poem to explore the delicacy of Whitman's music:

Listen again to Whitman's opening line: 'Word over all, beautiful as the sky.' The line is flawless iambic pentameter; he uses a trochaic substitution in the first foot, a hovering spondaic echo between the second and third feet, a daring and yet perfectly traditional inversion; and he successfully runs two light stresses before the final strong stress. (Prose, 9)

Obviously, iambic pentameter soon appears everywhere by this method, just as any scansion tends to one's personal tunings. ${ }^{10}$ Yet Wright challenges us to hear, really hear, Whitman. He challenges us to be free 
enough to accept any laws-free verse doesn't mean no meter, or it wouldn't be very free at all.

Further examination of "Reconciliation," which Wright quotes in its entirety, makes it clear exactly how deft Whitman the Prosodist is, and how wise Wright is to point us to this poem, even if he fails to say more about it. If, instead, we turn to what Sculley Bradley does with the poem, and move beyond his heavy-eared listening to the opening line, we encounter a sensible scansion, complete with his hovering accents (Bradley, 453)-he points out the lines' accents run, 4 (or 5), 8, 12, 6, 6, 6. It's the last three lines that interest him, how after the break of emotion and the haunting image of "the sisters Death and Night" (1881 Leaves, 321), the poem levels out:

For my enemy is dead, a man divine as myself is dead,

I look where he lies white-faced and still in the coffin-I draw near,

Bend down and touch lightly with my lips the white face in the coffin.

As Bradley writes, "The last three lines, given to quiet, reflective reaction, are all in six stresses" (453). But as Bradley fails to write, Whitman very skillfully manipulates the caesura, so the lines sound $2 / 4$, $5 / 1,6$. The poem, after all, is about war's end, about a re-Union, about the conclusion to the most frightening event-personally, philosophically, politically, morally-Whitman had to suffer. The fourth and fifth lines of the poem embody that struggle, the last the reconciliation-the line is a long gush of emotional re-integration. Line two's wish, "Beautiful that war and all its deeds of carnage must in time be utterly lost," is enacted with the poem's end: the closing lines' music allows no separating rests, no carnage. That's as true a reconciliation as Whitman could capture.

The poem, undoubtedly one of Whitman's loveliest, argues Wright's case soundly: delicacy, indeed. Wright says, "He moved beyond the permissive variations of iambic; and he is not afraid of the new musical possibilities out there, so he brings some of them back with him" (Prose, 9). Wright's image of Whitman as an explorer intrepidly staking out poetics incognita is all the more attractive since it would appeal so to Whitman himself. The Whitman of wild abandon is killed by Wright's essay and is replaced by a poet finely tuned to all the musics that fullness and silence can give him.

Wright further validates Whitman's lessons with his own poems. For example, the title poem of To a Blossoming Pear Tree (1977):

Beautiful natural blossoms,

Pure delicate body,

You stand without trembling.

Little mist of fallen starlight, 
Perfect, beyond my reach,

How I envy you.

For if you could only listen,

I would tell you something,

Something human.

An old man

Appeared to me once

In the unendurable snow.

He had a singe of white

beard on his face.

He paused on a street in Minneapolis

And stroked my face.

Give it to me, he begged.

I'll pay you anything.

I flinched. Both terrified,

We slunk away,

Each in his own way dodging

The cruel darts of the cold.

Beautiful natural blossoms,

How could you possibly

worry or bother or care

About the ashamed, hopeless

Old man? He was so near death

He was willing to take

Any love he could get,

Even at the risk

Of some mocking policeman

Or some cute young wiseacre

Smashing his dentures,

Perhaps leading him on

To a dark place and there

Kicking him in his dead groin

Just for the fun of it.

Young tree, unburdened

By anything but your beautiful natural blossoms

And dew, the dark

Blood in my body drags me

Down with my brother. ${ }^{11}$

Shirley Clay Scott sums up Wright's dilemma here: "But in this poem he has to choose between his two loves, the beauty of the earth and the cursed of the earth, and there is no question about his choice . . . the imagery detaches the subject from external nature and connects man to his life and death only through the link with life and death of another man."12

There is also the poem's music to consider. A rhythm of three has to jump out at every reader, "Beautiful natural blossoms, / Pure delicate body, / Worry or bother or care, / the ashamed hopeless / Old man." 
The lines themselves, not surprisingly, tend to be built around three accents. Nonetheless, it's the three lines built around two beats"Something human" and "We slunk away" and "and dew, the dark"that tell our bodies the poem. Wright cleverly moves from the trochaic meter constantly associated with the tree, to the iambic movement of the narrative (the human story), to a caesura suggesting the necessary separation of any human story. Whitman's lesson about caesuras is learned well, in a poem similar to "Reconciliation"; both are about the painful recognition of how similarly we share our separation. Instead of the sisters Death and Night, Wright gives us the pear tree-inhumanly beautiful, beautifully inhuman. The slinking away and the dark and the dew are as human as anyone can get, and the music of this free verse poem (how ironic that name is in this case) drives the point home, ever so delicately. Learning to listen, we learn to write.

Clearly it's impossible to say "Reconciliation" led directly to "Pear Tree." But the exercise of listening opens one's ears, just as Whitman himself opened the poem. Eniko Bollobas writes, "In 1855 Whitman shook the foundation of accent-and-syllable counting regularity: his 'barbaric yawp' counted accents, if anything, and replaced the traditional prosodic unit of the foot with higher prosodic and grammatical units, the line, the phrase, the sentence."13 Whitman allowed for a lot; unfortunately most of his heirs wrote the prose chopped into arbitrary line lengths that Ezra Pound so detested. Yet he also led to Wright.

Robert Hass sums up the historic moment, describing the advent of balloon frame construction in housing:

It was invented by a man named George Washington Snow in the 1850 s and 1860s, about the same time as Leaves of Grass. . . . The balloon frame . . . made possible a light, quick, elegant construction with great formal variability and suppleness. For better or worse. .. . The balloon frame, the clapboard house, the Windsor chair. American forms, and Leaves of Grass, which abandoned the mortise and tenon of meter and rhyme. ${ }^{14}$

Wright's essay wants to lead us toward the better, away from the worse. It accomplishes such teaching most slyly when Wright seems to do nothing but quote four lines from the bird's song in "When Lilacs Last in the Dooryard Bloom'd" (although Wright doesn't even say which poem the stanza comes from-that's how indirect his essay can be at times). Wright says, "We need only listen" (Prose, 9), and then quotes:

Come lovely and soothing death,

Undulate round the world, serenely arriving, arriving,

In the day, in the night, to all, to each,

Sooner or later delicate death. (1881 Leaves, 335)

Preceding this quote, Wright discusses how Whitman "moves beyond the permissive variations of iambic . . . perhaps they are the quantitative 
possibilities of the classical languages" (my ellipsis; Prose, 9), and thereby informs us how to read this hauntingly musical passage. Whitman's first line seems ordinary, if irregular-a trochee, an anapest, and an iamb. It's the second line that seems to resist scansion: it's either five feet or seven, but seven feet leaves us with an extra syllable that's hard to scan around.

Simply focusing on the words tells us a different metrical story, as Whitman seems to favor tri-syllabic diction in this line, to the point of echoing "arriving" at line's end (a clever way to show death is constantly approaching, constantly not quite here). If we take Wright's hint about "classical languages," though, the line is easy to scan: we end up with an amphibrach, an amphimac, and three more amphibrachs; it's as if Whitman, and his bird announcing death, can call up some ancient poetic music all their own. The line, when heard this way, ends up dominated by unstressed syllables, and the solitary amphimac seems out-of-place, nearly forcing "round" and "world" to be heard unstressed, which only makes sense-death's song un-accents the world, particularly when death claims one as great as Lincoln. Five lines later in "Lilacs" Whitman suggests he's conscious of what he's up to when he writes, "Dark mother always gliding near with soft feet" (1881 Leaves, 335); death is so delicate she traffics in unaccented syllables. (The entire stanza has 18 stressed, and 23 unstressed syllables, a ratio traditionally closer to prose than poetry.)

Wright sums up his section on the delicacy of Whitman's music by again echoing his two fears for the future of poetry, namely "the old-world elegance of Longfellow . . . [and] the curtain of aimless destructiveness, which is eventually not even destructive but just trivial" (Prose, 10). Yet, learning to listen in the ways Wright offers could only show us how much Whitman escaped both fates, and how much he has to teach us.

To continue pointing out Whitman's lessons, Wright next proceeds to Whitman's diction. Somehow the essay grows more and more delicate itself; as Wright moves towards the intangibles of poetry, he leaves even more of the responsibility with us, and therefore the task of an essay such as this one grows.

What Wright claims awaits us in Whitman's diction is a great ability to be precise about the fierce without running from its power or hoping to overpower it. Wright writes, "He is able to retain his delicacy, which is a power of mind as well as a quality of kindness. . . He is sensitive precisely about things that are often in themselves harsh, even brutal" (Prose, 11). Wright has in mind the Drum-Taps poems in particular, their whispering insistence on the horrors of the war.

He quotes "A March in the Ranks Hard-Prest, and the Road Unknown" in its entirety, but elaborates on Whitman's focus: the 
wounded young man's face. "He suddenly looms up out of the confusion and darkness; he has been shot in the abdomen; his face, buffaloed by shock, is "white as a lily' " (Prose, 13). Wright's own "buffaloed" nearly outdoes Whitman's metaphor, a metaphor which isn't unusual, Wright knows that. What amazes Wright is the triple play Whitman pulls off: he comes up with an apt metaphor, he attempts to deal with non-poetic subject matter, and he writes about personally painful experiences - "in him they become a single act of creation" (Prose, 13). That act of creation, what Wright later calls an "act of the imagination," becomes the major issue for the rest of the essay. How can poetry help us imagine our lives? And specifically, how can poetry help us imagine the drastic end of a life?

As with "Reconciliation," it's useful to examine "A March in the Ranks" more closely, now that Wright has pointed the way. The poem seems set in a forgotten bolgia of Dante's Inferno - pitch black, fiery light, vague forms. Whitman even comes upon the hospital out of the "heavy wood," his own selva oscura. Whitman isn't in control of the situation of the poem; the entire direction of the army is confused, marching down the "road unknown," which just happens to dangle off the first ten syllables of the opening line. Whitman's usual ecstatic use of participles is subverted in the third line with "retreating," far from the "-ing" dominated awakening of the poet he celebrated in "Out of the Cradle." At mid-poem the lad's face looms, and Whitman begins whispering with parentheses:

At my feet more distinctly a soldier, a mere lad, in danger of bleeding to death, (he is shot in the abdomen, )

I stanch the blood temporarily, (the youngster's face is white as a lily,) . . (1881 Leaves, 305)

These quiet clues hit hard. They seem as if they forced their way into the bulk of the poem, nearly daring Whitman to utter them. He does. The clauses in a way become their own poem, death's peace answering the bustle of the hospital; the lily nature's first appearance in the poem beyond the heavy wood, which isn't much more than darkness. There's also the rhyme of "temporarily" and "lily," enough of an echo to leave us the boy a cut flower in our hands, and us inconsolable. It's clear that returning to the general rush can't help Whitman himself shake the image; he writes, "I see again the forms." The poem brings it all back.

The poem winds to its end, like "Reconciliation," with a kiss: "But first I bend to the dying lad, his eyes open, a half-smile gives he me." The subject and object at the line's end are nearly one, meeting on the same side of the verb. Also, the "he me" rhyme takes us back to temporarily-lily, and another identification with death is made. The close: "Resuming, marching, ever in darkness marching, on in the 
ranks, / The unknown road still marching." The darkness, now, isn't merely night. And the painful hemstitch leaves the road itself marching off, while Whitman, one may guess, is still with the lad.

At least in his thoughts, but that's what poems are about. Robert Hass, again, could be writing about both poets when writing about Wright, "What mattered to me in these poems was that their lean, clear plain language had the absolute freshness of sensibility" (Hass, 27), which is another way to say imagination. Wright himself claims, "He [Whitman] deliberately seeks in American life the occasions and persons who are central to that life; he sometimes finds them harsh and violent, as in the war; he responds to the harshness with a huge effort of the imagination: to be delicate, precise, sensitive" (Prose, 13).

Again it is worthwhile to turn to one of Wright's poems and see such imagination at work. From To A Blossoming Pear Tree comes "Hook":

I was only a young man

In those days. On that evening

The cold was so God damned

Bitter there was nothing.

Nothing. I was in trouble

With a woman, and there was nothing

There but me and dead snow.

I stood on the street corner

In Minneapolis, lashed

This way and that.

Wind rose from some pit,

Hunting me.

Another bus to St. Paul

Would arrive in three hours,

If I was lucky.

Then the young Sioux

Loomed beside me, his scars

Were just my age.

Ain't got no bus here

A long time, he said.

You got enough money

To get home on?

What did they do

To your hand? I answered.

He raised up his hook into the terrible starlight

And slashed the wind.

Oh, that? he said.

I had a bad time with a woman. Here,

You take this. 
Did you ever feel a man hold

Sixty-five cents

In a hook,

And place it,

Gently

In your freezing hand?

I took it.

It wasn't the money I needed.

But I took it. (Tree, 58-59)

Again, it seems, a whispering. What stands out, since it stands alone, is "Gently," the fulcrum about which the poem pivots. How might a one-word line be learned from Whitman? Like "A March in the Ranks," "Hook" seems to fill with blur and doubling: two men with women trouble, the repeated "nothings," the question that answers, the repetition of "I took it." What stands out, singly, is the action, and what stands out about the action is its quality-gently (so close to delicately). The action also earns its own stanza a sentence long. Literally and syntactically, nothing in the poem means as much as "gently"-a seeing similar to a lily lost in the horror of a field hospital. Both poems are narrowings, simply by different means-Whitman fills the page to fight pain, Wright empties it. Yet neither shrugs the pain off.

As an aside, one reason for the change in line lengths is symbolized by an event that occurred just a year after Whitman's death. In 1893, Frederick Jackson Turner delivered his frontier thesis, and the world of the pioneers, at least according to historians, was closed. Manifest Destiny had largely been manifested. The Brooklyn Bridge replaced Whitman's ferry ten years before. The land was closing up, and the thrust of expansion had to turn elsewhere. Bollobas claims, "Naming becomes very important for Whitman, because here lies the essence of his poetic attitude: in asserting himself 'Adamically'" (Bollobas, 68). She doesn't consider what happens when everything is named, when Adam has to share his Eden with too many others. Years later, Allen Ginsberg does, and his ode to Whitman, "A Supermarket in California," apes Whitman's extended line, but leaves him lost in the supermarket America has become. The lengthy Whitman line turns ironicit's too big for twentieth century writers to keep all the crap of America out. Ed Folsom writes, "Ginsberg's absorptive lines, imitating Whitman's, seem to accumulate empty or absurd images rather than the rugged, ennobling catalogs Whitman could so easily collect as he wandered the roads of America." 15

Times have changed. Wright, in his bitter, ironic "Minneapolis Poem" (how that city works as a magnet for his worst moments), writes, "The old man Walt Whitman our countryman / Is now in America our 
country / Dead. / But he was not buried in Minneapolis / At least" (Collected Poems, 141). The parody of Whitman's parallelism sets up equivalences between Whitman and America and leaves them both dead. Another one-word line for an inability to say more. Winning the freedom to talk also wins the freedom to be silent; the balloon-frame house gets to be both inflated and deflated. Whitman, at his largest, can embrace both. For what are the parenthetical statements of "A March in the Ranks" but his voice barely audible?

It is impossible to continue to discuss diction and music without discussing form, the topic Wright wisely saves for last. It's the word over all in poetry, encompassing music, diction, voice, anything a poem can be reduced to. Wright turns to the 1855 Preface, as many others have done, ${ }^{16}$ to quote: " $T$ The rhythm and uniformity of perfect poems shows the free growth of metrical laws, and bud from them as unerringly and loosely as lilacs and roses on a bush, and take shapes as compact as the shapes of chestnuts and oranges' "' (quoted in Prose, 14). Wright could also have quoted this passage: "It [American poetry] is to be indirect and not direct or descriptive or epic . . . here the theme is creative and has vista . . . the solid and beautiful forms of the future where there are now no solid forms" (1855 Leaves, 8; my ellipses). Here, of course, comes all the talk of Whitman's organic form, as inherited from Coleridge and the German Romantics (see Bradley, 440). Yet, what lingers in the second quote is vista-an all-encompassing sense of past, present, and future-which doesn't sound like poetry simply doing its own thing in a natural, random way.

Wright himself dodges the notion of organic form, finds it too much a label. Instead, he suggests the following about the first quote from the 1855 Preface:

It is this kind of formal growth that, I believe, gives special appropriateness to Whitman's mention of 'shapes of chestnuts and oranges.' These fruits do indeed have 'shapes'-delicate shapes indeed. And they are compact, not diffuse. Their life depends on their form, which grows out of the form of blossoms, which in turn grew out of the forms of trees, which in turn grew out of the forms of seeds. If I followed the changes that overwhelmed an orange seed, I should be startled at the unexpected form of each stage of growth; but the form would be there nonetheless, however unexpected: at once undreamed-of and inevitable. (Prose, 16)

Seed, tree, blossom, fruit. Form becomes movement; literally organic growth. Which is how Wright discusses "I Heard You Solemn-Sweet Pipes of the Organ"; yet another case where he hands us the poem, leaving us to listen:

I heard you solemn-sweet pipes of the organ as last Sunday morn I pass'd the church, Winds of autumn, as I walk'd the woods at dusk I heard your long-stretch'd sighs up above so mournful, 
I heard the perfect Italian tenor singing at the opera, I heard the soprano in the midst of the quartet singing;

Heart of my love! you too I heard murmuring low through one of the wrists around my head,

Heard the pulse of you when all was still ringing little bells last night under my ear. (1881 Leaves, 110)

Five lines from a church to a lover's bed, with a walk in the woods and a night at the opera in between. Wright's clue: "A simple poem of five lines. Whitman addresses four different sounds. In these apostrophes and in his arrangement of them we can find the form of the poem" (Prose, 15). The sounds: organ, wind, tenor/soprano/quartet, heart/ pulse. But there's really a fifth sound Wright doesn't give Whitman credit for-the ringing little bells. Without them, we don't wind up back in church, although a new church, a real church-that of love. (Remember, Whitman is passing by in the first line). The poem builds, too, from music by instrument to nature's music, from music by voice to the body, unvoiced. The movement towards the bed is a movement towards the self (via the other). The movement also makes the love brilliantly strong, as it climaxes a crescendo of sounds that includes nature itself and the opera Whitman so loved. And the sound-a "murmuring" that deafens the organ, the wind, the opera.

Wright, wisely, leaves such dissection to essays such as this one. Instead, he prefers to offer vague directions - "For he uses parallelism not as a device of repetition but as an occasion for development" (Prose, 15 ), and, "We discover the form of the poem as we read it; and we know what it is only after we have finished" (Prose, 16).

The process of poetry, of form, works as follows: "We suspect undiscovered laws of possibility-a movement not by linear connection, nor even by the co-centric circles that structure Romantic poems, but by overlapping circles whose centers are all decentered from each other. .. . Each metamorphosis becomes only a strand of the knot, or web of the whole poem, that vanishes in the tangle." 17 Put more poetically by D.H. Lawrence, "But there is another kind of poetry: the poetry of that which is at hand: the immediate present. In the immediate present there is no perfection, no consummation, nothing finished. The strands are all flying, quivering, intermingling into the web, the waters are shaking the moon" (quoted in Stitt, 143).

Actually, while the above quotes apply to Whitman, they were used by Richard Jackson and Peter Stitt to discuss James Wright's uses of form, uses that clearly change between his books Saint Fudas and The Branch Will Not Break. Here's "Miners" from Branch: 
1.

The police are probing tonight for the bodies

Of children in the black waters

Of the suburbs.

2.

Below the chemical riffles of the Ohio River,

Grappling hooks

Drag delicately about, between skiff hulks and sand shoals,

Until they clasp

Fingers.

3.

Somewhere in a vein of Bridgeport, Ohio;

Deep in a coal hill behind Hanna's name;

Below the tipples, and dark as a drowsy woodchuck;

A man, alone,

Stumbles upon the outside locks of a grave, whispering

Oh let me in.

4.

Many American women mount long stairs

In the shafts of houses,

Fall asleep, and emerge suddenly into tottering palaces. (Collected Poems, 118-119)

Like "Solemn-Sweet Pipes," four images. This time, soundless, in some ways sightless; the emphases seem to be on the search-probing, grappling, clasp, stumbles, emerge. If we take the numbering as a clue, the conclusion should be a conclusion, but it seems more like a reversal, a return to the suburbs of lost youths, a turn away from the strip-mine ravaged Ohio Valley. That's fitting, too, somehow - a progression of descent, a "mounting" of "shafts." The poem is a continual search for our suicides - children hunted by police, the actual body-dragging, the man knocking at a grave (in another poem Wright says, "Earth is a door" [Collected Poems, 84] ), the women adrift in dreams, their houses given away to palaces, tottering, yet still. It would be easy to explain the poem away. Suffice to say that Wright's web shimmies akin to Whitman's, "Mark'd how to explore the vacant vast surrounding" (1881 Leaves, 450). Both poems exhibit form at its most organic, "indirect" yet full of "vista."

Wright says, "Form in Whitman is a principle of imagination: the proliferating of images out of one unifying vision" (Prose, 17). Each poem becomes its own invention of form, a creation of "the solid and beautiful form of the future where there are now no solid forms"- of course, since the poems of the future aren't written yet. Wright himself turns testy in an interview when a non-logical jump similar to those in "Miners" (or "Sweet Pipes," for that matter) is called a device: 
Wright: It's not a device.

Michael Andre: That method.

Wright: It's just an understanding. (Prose, 147)

The vague words tend to mount-understanding, vision, imagination, vista. But isn't poetry an attempt to name this very unnameable? "The best of the earth cannot be told anyhow" (1881 Leaves, 224). Or as David Daiches says, in a manner more full of possibility, "Whitman's cumulative method also means that his poetry is more open-worked than the kind of poetry which modern criticism is equipped to handle. Its meaning is developed lengthwise, not depthwise; words acquire new meanings by reiteration, and images take on significance by functioning in a series" (quoted in Bollobas, 98). Gay Wilson Allen describes Whitman's parallelism similarly: "He tends to build up to an emotional, if not logical, climax" (Allen, 221).

The march of parallelism allows formlessness form. It gives the poet steps to leap from, ways to peer over and through things. Whitman, as the first major English-writing practitioner of parallelism, further helps put up the balloon frame house of poetry. A poem must move. ${ }^{18}$

Wright offers "a further example of the parallel form, which is delicate and precise and therefore very powerful but which is not based on the repetition of sentence structure" (Prose, 17) when he quotes the opening six lines of Section 8 of "Song of Myself." The growth of form here is rather evident:

The little one sleeps in its cradle,

I lift the gauze and look a long time, and silently brush away flies with my hand.

The youngster and the red-faced girl turn aside up the bushy hill, I peeringly view them from the top.

The suicide sprawls on the bloody floor of the bedroom,

I witness the corpse with its dabbled hair, I note where the pistol has fallen. (1881

Leaves, 35-36)

In typical Wright fashion, he merely quotes the passage, but his notion of form is easy to see-these lines are Whitman's version of the Sphinx's riddle, as humans go out of the cradle up the hill of life and into the pit of death in a rush.

But there is even more parallelism in this passage. The second of every pair of lines stresses Whitman as see-er, and the uglier the scene, the sooner the I of each line sees/acts. Of all the form to point to Whitman, of all the parallelism, Wright carefully selects a passage that stresses Whitman as compassionate seer. It's not surprising Wright closes up the discussion of Whitman's form with the claim, "Form in 
Whitman is a principle of imagination; the proliferating of images out of one unifying vision" (Prose, 17).

Unfortunately, critics tend to label Wright's organic form (learned via Whitman) as a type of surrealism, that miserably abused word. Wright replies, in response to a query about "Miners" and surrealism: "It's influenced by surrealism. I don't think the poem itself is surrealistic. I think it's extremely formal, very traditional. The images are all parallel to one another. It's as formal as the end of Lincoln's Gettysburg Address. I don't mean it's as good" (Prose, 181). The only tradition he can be referring to is Whitman's. The reference to Lincoln is possible circumstantial evidence that Whitman is on Wright's mind. The mention of the Gettysburg Address also reminds us where we most tend to see parallelism -in prose. Bollobas writes, "The prosodic avant-gardism of Whitman is characterized by an overt preference for the 'devices' of ordinary and oratorical language, by bringing speech-strategies into the text, and by substituting prose rhetoric for traditional poetic artifice" (71).

So when Wright's essay turns to Spanish writers, he's not after surrealism at all, but Whitman's ghost, filtering it through the Spanish poets he claims share with Whitman "the belief in the imagination as the highest flowering of human life" (Prose, 19). As mentioned earlier, Wright translated more and more from the Spanish during the 1960s: Cesar Vallejo in 1963, Jorge Guillen in 1965, Pablo Neruda in 1967. And in Wright's Collected Poems, a selection of translations are placed between Saint Fudas and The Branch Will Not Break. It seems that during this period Wright could not escape Whitman and his "enormously courageous willingness to leap from one image into the unknown, in sheer faith that the next image will appear in the imagination" (Prose, 19). What more is poetry than imagination bridled to form?

For one last look at the delicacy of form in both poets, it's worthwhile to turn away from Wright's essay and look at two poems written 109 years apart. The surface matter is the same, but that's nearly all. The first section of Whitman's:

\section{Blood Money}

Of olden times, when it came to pass

That the beautiful god, Jesus, should finish his work on earth,

Then went Judas and sold the divine youth,

And took pay for his body.

Curs'd was the deed, even before the sweat of the clutching hand grew dry;

And darkness frowned upon the seller of the like of God,

Where, as though earth lifted her breast as though to throw him from her, and heaven refused him,

He hung in the air self-slaughter'd. 
The cycles, with their long shadows, have stall'd silently foreward, Since those ancient days-many a pouch enwrapping meanwhile Its fee, like that paid for the son of Mary.

And still goes one, saying,

"What will ye give me, and I will deliver this man unto you?"

And they make the covenant, and pay the pieces of silver. ${ }^{19}$

The whole of Wright's:

\section{Saint fudas}

When I went out to kill myself I caught

A pack of hoodlums beating up a man.

Running to spare his suffering I forgot

My name, my number, how my day began,

How soldiers milled around the garden stone

And sang amusing songs; how all that day

Their javelins measured crowds; how I alone

Bargained the proper coins, and slipped away.

Banished from heaven I found this victim beaten,

Stripped, kneed, and left to cry. Dropping my rope

Aside, I ran, ignored the uniforms:

Then I remembered bread my flesh had eaten,

The kiss that ate my flesh. Flayed without hope,

I held the man for nothing in my arms. (Collected Poems, 84-85)

Two very different poems. One sprawling, enjambed. The other enjambed, yet iambic pentameter. One public, raging, issue-driven. The other private, pitying, reflective. Walt Whitman wrote "Blood Money" in 1850 , on the way to his invention of free verse, to the 1855 Leaves of Grass where that free verse would help him claim, "What is commonest and cheapest and nearest is Me" (1855 Leaves, 36). It is unclear what happened to Whitman to bring about such a change in five years, but that issue is beyond this essay's scope.

James Wright wrote "Saint Judas" in 1959. Ignoring the Petrarchan sonnet form, the sentiment surely sounds like Whitman, ever eager to embrace all, even the prostitute. (Why "Blood Money" seems unlike Whitman we'll get to.) When Robert Hass describes Wright's work as "a dream of transcendence and a dream of community" (Hass, 33), he might be glossing all of Whitman. But the iambic pentameter doesn't seem to connect-Wright and Whitman might seem poets of the same mind, not the same body.

Yet "Saint Judas" betrays itself. As with any good poem, form and content must merge. The regularity of Wright's iambic pentameter doesn't really break down until the sestet; he ignores the uni-form of the sonnet as much as Judas tries to ignore the uniforms. The feminine endings of "beaten" and "eaten" suggest the fall. The violence of 
"Stripped, kneed and left to cry. Dropping my rope" wrenches the metrics of the line with an initial spondee and fourth foot trochee. The off-rhyme of "uniforms" and "arms" aches with the distance Judas wants to achieve from the soldiers, the distance he feels from the beaten man. The run of three unaccented final syllables before the final accent empties the poem out, leaves us holding the nothing of man.

What Wright learns is he can't have his Judas and hang him, too, not in a sonnet. Wright has to defy the form to discover Judas, to say what he claims he was after in the poem: "You would think he'd be a completely cold person. And yet he couldn't have been to experience such complete despair" (Prose, 166).

As for "Blood-Money," it's not a poem about discovery, for Whitman hasn't learned how to discover yet. It's message-driven, and a message has no room for the imagination (that's not to say imagination cannot have room for a message). The form is received: cant and rant. The same is true for the two earliest poems in the Deathbed Leaves of Grass, "A Boston Ballad" (1854) and "Europe" (1850): poems with too much to say not to be essays in a poem's clothing. All three are incredibly political, embittered about the Fugitive Slave Law, angered over the trial of a fugitive slave, and excited by the revolutions of 1848 . Whitman's preconceived ideas lead him to received forms, instead of a searching form that catches itself saying something. As Shirley Clay Scott says about Wright, "The poem's informing power, however, derives not from knowledge or experience that existed prior to the poem, but from experience that the poem achieves with the leap from experiential order renewed by language to the ideal order created by language" (Scott, 56). Or, as Wright might simply say, "The poems aren't delicate."

"Saint Judas" might be a fourteen line model for Wright's poetic career. He began with two quite formal books, The Green Wall (lauded by Auden, no less) and Saint Fudas. The rest, however, pulled away, not composed metrically, ${ }^{20}$ but after a new form. In 1969, Richard Howard joked about the split in Wright's books, claiming he had written "two in verse and two (it is tempting to say) inversely."21 While it is difficult to say what led Whitman away from the notion of the line he battled with in "Blood-Money" (who would expect an enjambment like, "enwrapping meanwhile / Its fee" in Whitman?), it seems clear Whitman is one of the things that happened to Wright to lead him into the sestet of "Saint Judas" and beyond. As Wright says in an interview, "Well it's strange how an influence works on one's mind. . . . It may take a long time for the movement of one's own emotion to come out and make sense" (Prose, 164). While Wright refuses to spell out all of the delicacy there is in Whitman, he points us in many right directions, helping us encounter Whitman anew. 
To end this essay, it might be best to point to a place where Wright seems most receptive to Whitman, just in the way Wright ends his "Delicacy" essay by pointing us to poems by Bly, Levertov, Simpson, and Ignatow in which he feels Whitman lives on. "Leaving the Temple at Nimes," the second to last poem in Wright's posthumous (a composting, almost) This fourney (1980), not only echoes Whitman's lessons, it mentions him by name. It's hard not to draw a big metaphor about a last book called This Fourney written by a lover of the Singer of the Open Road, particularly when that Singer is repaid at the very end for a lifetime of debts. In the poem, Wright breaks four leaves from an ivy on a pine at the Temple of Diana, a gesture similar to Whitman's breaking a sprig of lilac for "him I love" (1881 Leaves, 328). The first two leaves are to honor Diana and the "solitary poet" Ausonius. As for the other leaves, the poem ends:

And I will send one ivy leaf, green in winter,

Home to an American girl I know.

I caught a glimpse of her once in a dream,

Shaking out her dark and adventurous hair.

She revealed only a little of her face

Through the armful of pussy willow she gathered

Alive in Spring,

Alive along the Schuylkill in Philadelphia.

She will carry this ivy leaf from Diana's pine

As she looks toward Camden, across the river,

Where Walt Whitman, the chaste wanderer

Among the live-oaks, the rain, railyards and battlefields

Lifts up his lovely face

To the moon and allows it to become

A friendly ruin.

The innocent huntress will come down after dark,

Brush the train smoke aside, and leave alone together

The old man rooted in an ugly place

And a girl with an ivy leaf revealing her face

Among fallen pussy willow. ${ }^{22}$

Wright has carried on the program of adhesiveness - a discovery of "lovingkindness"- by telling Whitman he need not fear becoming the live, lonely oak in Louisiana growing; he'll be broken and re-grafted, "alone together" with poets forever. Walt "the friendly ruin": not merely stroke-crippled in Camden, Wright leaves us with "Walt Whitman, the chaste wanderer," a delicate man who survived this journey with an armful of poetry white as a lily. Honed, bone-clean, pure. 


\section{NOTES}

1 James Wright, Collected Prose, ed. Annie Wright (Ann Arbor: University of Michigan Press, 1983), 133. Hereafter Prose.

2 Other influences, also, led Wright to his "new Form"-among them Georg Trakl, Robert Bly, Robert Penn Warren, and translations of numerous Spanish writers (themselves influenced, as Wright notes, by Whitman).

3 Wright later admitted he was wrong about much of the Beat movement, and he grew to respect the work of Corman, Snyder, Ginsberg, and Ferlinghetti in particular (see Prose, 142-143).

4 Walt Whitman's Leaves of Grass, ed. Malcolm Cowley (New York: Penguin, 1959), 12. Hereafter "1855 Leaves."

5 In fact, near the end of the "Delicacy" essay, Wright heralds the Malcolm Cowley reprinting of the first edition of Leaves as the best poetry book of 1959 .

6 James Wright, Collected Poems (Middleton, CT: Wesleyan University Press, 1971), 60-61.

7 Leaves of Grass: Comprehensive Reader's Edition, ed. Harold Blodgett and Sculley Bradley (New York: New York University Press, 1965), 514. Hereafter "1881 Leaves."

8 Sculley Bradley, "The Fundamental Metrical Principle in Whitman's Poetry," American Literature 10 (January 1939), 451.

9 Paul Fussell, “Free Verse,” Antaeus 30-31 (1978), 296-308.

10 Sculley Bradley finds only four stresses in this first line, but he's hunting for Anglo-Saxon blood beats (see Bradley, 452).

11 James Wright, To a Blossoming Pear Tree (New York: Farrar, Straus and Giroux, 1977), 60-61. Hereafter Tree.

12 Shirley Clay Scott, "Surrendering the Shadow: James Wright's Poetry," Ironwood 10 (1977), 62.

13 Eniko Bollobas, Tradition and Innovation in American Free Verse: Whitman to Duncan (Budapest: Akademai Kiado, 1986), 14.

14 Robert Hass, Twentieth Century Pleasures (New York: Ecco, 1984), 70-71.

15 Ed Folsom, "Talking Back to Walt Whitman, in Jim Perlman, Ed Folsom, and Dan Campion, eds., Walt Whitman: The Measure of His Song (Minneapolis: Holy Cow!, 1981), xlv.

16 See Gay Wilson Allen, The New Walt Whitman Handbook (New York: New York University Press, 1986), 210; and Bradley, 440.

17 Richard Jackson, "The Time of the Other: James Wright's Poetry of Attachments," Chowder Review 10-11 (1978), 134.

18 Even Ezra Pound, bitter heir of Whitman, unwanted forefather to Wright, laments a lack of motion in poetry: "The defect of earlier imagist propaganda was not in misstatement but in incomplete statement. The diluters took the handiest and easiest meaning and thought only of the STATIONARY image." See Pound, ABC of Reading (New York: New Directions, 1960), 52. 
19 Whitman, Early Poems and Fiction, ed. Thomas L. Brasher (New York: New York University Press, 1963), 47-48.

20 An overstatement, as several poems in each of Wright's books are strictly metrical, including "May Morning" in This fourney-a prose poem that is actually a perfectly rhymed and metered sonnet.

21 Richard Howard, Alone with America (New York: Atheneum, 1980), 662.

22 James Wright, This fourney (New York: Vintage, 1982), 85-86. 